\title{
Exogenous $\beta$-mannanase supplementation improved immunological and metabolic responses in lactating dairy cows
}

\author{
B. M. Roque, ${ }^{1}$ G. C. Reyes, ${ }^{1}$ T. A. Tewoldebrhan, ${ }^{1}$ J. A. D. R.N. Apphuamy, ${ }^{1}$ J.-J. Lee, ${ }^{2}$ S. Seo, ${ }^{3}$ \\ and E. Kebreab ${ }^{1 *}$ \\ ${ }^{1}$ Department of Animal Science, University of California, Davis 95616 \\ ${ }^{2}$ CTCBio Inc., Seoul 05842, Republic of Korea \\ ${ }^{3}$ Department of Animal Biosystem Sciences, Chungnam National University, Daejeon 305-764, Republic of Korea
}

\section{ABSTRACT}

Exogenous enzymes have been used to improve nutrient utilization in several species of livestock, particularly swine and poultry. In addition, improved immunological and metabolic traits have been reported in nonruminants. The objective of this study was to determine the effects of $\beta$-mannanase supplementation on milk yield and composition, and immunological and metabolic responses in lactating Holstein dairy cows. Two weeks after calving, 20 Holstein cows (10 multiparous and 10 primiparous) were blocked by parity and assigned to 1 of 2 diets for $182 \mathrm{~d}$. All cows were housed in the same environment and fed the same basal diet. The basal diet of the treatment group was supplemented with $\beta$-mannanase (CTCBio Inc., Seoul, South Korea) at $0.1 \%$ of concentrate dry matter. No differences were detected between the control and enzyme supplement groups in milk yield parameters or milk composition. Supplementation of $\beta$-mannanase enzyme reduced blood haptoglobin levels in supplemented multiparous cows compared with controls. Furthermore, nonesterified fatty acid concentration levels tended to be lower in cows fed $\beta$-mannanase, regardless of parity. Neither immunoglobulin G nor milk somatic cell count was affected by $\beta$-mannanase supplementation, regardless of parity. The number of insemination services tended to be lower in cows fed diets supplemented with $\beta$-mannanase. Results from this study suggest that supplementation of $\beta$-mannanase exogenous enzyme could help to reduce instances of systemic inflammation and decrease fat mobilization in lactating Holstein cows. Multiparous cows are considered susceptible to acute infections and inflammation; thus, the enzyme had a greater effect in multiparous cows.

Key words: $\beta$-mannanase, haptoglobin, lactating cow, immune response

Received August 17, 2018.

Accepted January 31, 2019

*Corresponding author: ekebreab@ucdavis.edu

\section{INTRODUCTION}

Ruminants typically consume diets containing relatively high amounts of forage, which contains cell wall fractions that have complex compounds such as $\beta$-mannans. These are typically known for their structural resistance to solubility, leading to high viscosity in feed and exhibiting antinutritive properties in animal feeds (Chauhan et al., 2012). The viscosity of $\beta$-mannan may depress digestion and absorption in the gut and reduce pancreatic enzyme activity within the small intestine of nonruminants (Ikegami et al., 1990). Additionally, $\beta$-mannans can potentially stimulate immune cells in gut epithelium, an integral part of the innate immune system (Duncan et al., 2002; Ausubel, 2005; Chauhan et al., 2012). The innate immune cells identify pathogens using distinct molecule, called pathogenassociated molecular patterns (PAMP), expressed on the surface of pathogens (Forsberg and Wang, 2006). Binding of PAMP to receptors present in innate immune cells activates those cells (Forsberg and Wang, 2006). These PAMP include complex polysaccharides such as $\beta$-mannan. Therefore, $\beta$-mannan in feeds can create a false signal of the presence of pathogens in the gut, initiating an unwarranted immune activation. Activation of the immune system has been shown to negatively affect energy balance in dairy cows (Kvidera et al., 2017). Hydrolysis of $\beta$-mannan can eliminate such a false signal in the gut. Moreover, hydrolysis of $\beta$-mannans releases mannan-oligosaccharides, which have been shown to improve gastrointestinal health or overall health and performance of poultry ( $\mathrm{Li}$ et al., 2010), dogs (Swanson et al., 2002), and dairy calves (Heinrichs et al., 2003).

The mannosidic bonds in $\beta$-mannans are hydrolyzed by enzymes called $\beta$-mannanases. $\beta$-Mannanases are glycoside hydrolases, a group that also includes cellulases and xylanases, and use mechanisms similar to those of cellulose and xylanase in identifying and accessing substrate (Tewoldebrhan et al., 2017). Exogenous $\beta$-mannanases have been extensively tested 
in monogastric animals for their effects on nutrient digestibility, growth, feed conversion efficiency, energy metabolism, and health (Jackson et al., 2003). Exogenous $\beta$-mannanases have been shown to withstand a wide range of $\mathrm{pH}$, temperature, and pepsin- and trypsin-induced proteolysis (Yang et al., 2015). There is a paucity of information on $\beta$-mannanase produced by rumen bacteria and therefore the significance of exogenous $\beta$-mannanase supplementation in ruminants. Nakai et al. (1994) observed that only 5 of 26 rumen bacterial strains were able to degrade more than $20 \%$ of the $\beta$-mannan in culture medium. About $80 \%$ of those strains were Butyrivibrio fibrisolvens. Fernando et al. (2010) showed that B. fibrisolvens in the rumen declined by about 10-fold as the forage:concentrate ratio changed from 100:0 to 60:40 in cattle, suggesting a lower abundance of the bacteria in cows fed typical North American diets.

Tewoldebrhan et al. (2017) previously studied supplementation of exogenous $\beta$-mannanase $(0.1 \%$ of concentrate DM) in mid-lactation dairy cows fed a diet including forage (corn silage and alfalfa hay) at $60 \%$ of DM. The diet included soybean meal and soybean hulls $(13.5 \%$ of DM), which are known to be rich in $\beta$-mannan. They observed lower SCC and unchanged milk yields even though DMI decreased in $\beta$-mannanase-supplemented cows. Overall, the results highlighted the potential of exogenous $\beta$-mannanase to improve nutrient utilization efficiency and health status in cows, which could be more important in an early stage of lactation, when cows undergo several immune challenges, lower DMI, and a negative energy balance (Sordillo and Aitken, 2009; Bradford et al., 2015). Therefore, the objective of this study was to examine the effects of exogenous $\beta$-mannanase supplementation on immunological and metabolic responses in lactating Holstein dairy cows in early and mid lactation.

\section{MATERIALS AND METHODS}

\section{Animals and Treatments}

All animal procedures were approved by Institutional Animal Care and Use Committee at the University of California-Davis. The study was conducted at the Dairy Unit of the Animal Science Department's Teaching and Research Facility at the University of California-Davis. During the experiment, the mean ambient temperature and relative humidity were $17.5^{\circ} \mathrm{C}$ and $59.9 \%$, with minima of $6.0^{\circ} \mathrm{C}$ and $32.5 \%$ and maxima of $32.3^{\circ} \mathrm{C}$ and $88.5 \%$, respectively. Two weeks after calving, 20 Holstein cows (10 multiparous and 10 primiparous) were matched for parity and milk yield, and assigned to 1 of 2 diets for approximately $182 \mathrm{~d}$ (including a 10-d ad- aptation period). Multiparous cows were selected based on the previous lactation's milk yield (MY), whereas primiparous cows were selected based on the first $14 \mathrm{~d}$ of pretreatment MY. All cows were housed together in a freestall barn equipped with Calan gates (American Calan, Northwood, NH). The treatment groups were a basal TMR diet only or a diet supplemented with $\beta$-mannanase (CTCZYME, patent 100477456-0000; CTC Bio Inc., Seoul, South Korea) at $0.1 \%$ of concentrate DM, which was given uncoated. The dosage of $\beta$-mannanase was according to Tewoldebhran et al. (2017), who determined that the enzyme at $0.1 \%$ of concentrate DM was optimal for reduced SCC and improved feed conversion efficiency. The enzyme product has been shown to be optimally active at a $\mathrm{pH}$ of 6.0 , suggesting that activity would be greater in the rumen than in the small intestine (Tewoldebrhan et al., 2017). Data on its effect on rumen microbial communities are very limited.

Ingredient and chemical composition of the basal diet are given in Table 1. Initial diet formulation was based on NRC (2001) to meet nutrient requirements for a cow consuming the average predicted DMI of $24.3 \mathrm{~kg} / \mathrm{d}$ and producing, on average, $34.4 \mathrm{~kg}$ of milk/d. Each cow was fed twice daily at 0800 and $1800 \mathrm{~h}$, with $65 \%$ of the ration fed in the morning and $35 \%$ in the afternoon, and received individual TMR calculated as $110 \%$ of the previous day's intake. For supplemented animals, the enzyme was offered by hand mixing it thoroughly with corn silage first and then mixing the corn silage with rest of the feed. The supplement was kept refrigerated as indicated for commercial use. All cows were fed the standard early-lactation diet for $2 \mathrm{wk}$ (covariate period) after calving. The lactating animals were then enrolled in the trial at $14 \pm 0.87 \mathrm{DIM}$ and housed in a covered freestall barn with access to ad libitum water and feed and an exercise area. The first $10 \pm 1.7$ (mean \pm SD) DIM of the period was used for adaptation of cows to diet before starting sample collection.

\section{Sample Collection and Analysis}

Feed offered to and refused by individual cows was weighed and recorded daily. Feed ingredients were collected and analyzed every 8 wk during the experiment, except for corn silage, which was collected and analyzed every $4 \mathrm{wk}$ to adjust for any changes in DM. Additionally, ort samples were collected once a week throughout the experiment. Samples of feed ingredients and orts were pooled by days for every 8 -wk period and stored at $-20^{\circ} \mathrm{C}$ until analyzed. About $200 \mathrm{~g}$ of feces was collected via rectal palpation or during voluntary defecation from each cow once weekly. Sampled feces of each cow were placed into plastic bags, sealed, and 
Table 1. Ingredients and chemical composition of the experimental $\operatorname{diet}(\%$ of DM unless otherwise noted)

\begin{tabular}{lc}
\hline Item & Value \\
\hline Ingredient & \\
Corn silage & 24.5 \\
Alfalfa hay & 25.5 \\
Steam-flaked corn & 10.6 \\
Distillers grain & 7.63 \\
Soybean meal & 8.26 \\
Rolled barley & 6.88 \\
Mineral mix & 1.09 \\
Soybean hulls & 9.42 \\
Cotton seed & 5.72 \\
Calcium carbonate & 0.16 \\
Salt (NaCl) & 0.19 \\
Chemical composition (\% of DM) & \\
DM & 65.4 \\
CP & 18.8 \\
ADF & 23.6 \\
NDF & 34.2 \\
Lignin & 4.60 \\
Ntarch & 20.5 \\
NE (Mcal/kg) & 1.53 \\
\hline
\end{tabular}

stored immediately at $-20^{\circ} \mathrm{C}$ until analyzed. Cows were milked twice daily at 0700 and $1900 \mathrm{~h}$ in a herringbone milking parlor equipped with WestfaliaSurge milk meters (GEA Farm Technologies Inc., Naperville, IL). Feed samples, orts, and fecal samples were sent to Cumberland Valley Analytical Services Inc. (Maugansville, MD) and analyzed for $\mathrm{DM}\left(135^{\circ} \mathrm{C}, \mathrm{AOAC}\right.$ International, 2000; method 930.15), CP $(6.25 \times$ Kjeldahl N, AOAC International, 2000; method 990.03), ADF (AOAC International, 2000; method 973.18), NDF (Van Soest et al., 1991), lignin (Goering and Van Soest, 1970), starch (Hall, 2009), ash $\left(600^{\circ} \mathrm{C}\right.$, AOAC International, 2000; method 942.05), macrominerals (Ca, $\mathrm{P}, \mathrm{Mg}, \mathrm{K}$, and $\mathrm{Na}$ ) and microminerals (Fe, Mn, Zn, and $\mathrm{Cu}$ ) (AOAC International, 2000; method 985.01). Milk samples were collected weekly from individual cows and stored at $4^{\circ} \mathrm{C}$ until all samples were analyzed for milk fat, protein, lactose, and MUN concentrations and SCC (Central Counties DHIA, Atwater, CA). A portion of each milk sample collected was placed in a 5 -mL conical centrifuge tube for $\mathrm{Ca}$ and $\mathrm{P}$ analyses. Samples were stored at $-20^{\circ} \mathrm{C}$ until sent for analysis. Mineral content in milk were measured by inductively coupled plasma atomic emission spectrometry (US EPA, 1994; method 200.7) at UC Davis analytical laboratory (Davis, CA).

Blood samples were collected from the coccygeal vessels once a week starting on 14 DIM through 186 DIM (a total of 25 samples per cow). Each week, blood was collected in 3 sample tubes; heparin coated, EDTA coated, and a non-anticoagulant tube. After collection, the tubes were placed on ice until they were centrifuged. Plasma (EDTA and heparin tubes) and serum (non-anticoagulant tubes) were extracted by centrifugation at
$3,500 \times g$ for $15 \mathrm{~min}$, and then placed into 2 -mL sample tubes and stored at $-20^{\circ} \mathrm{C}$ until analysis. Samples were randomized by week, cow, treatment, and parity for each 96-well microplate to reduce variability between microplates analyzed. Haptoglobin concentrations were analyzed using Tridelta Phase Haptoglobin Assay (cat. no. TP-801, Tridelta Development Ltd., Boonton, NJ) and plasma from heparin-coated anticoagulant tubes. Immunoglobulin $\mathrm{G}$ concentrations were analyzed using ELISA (Genway Biotech Inc., San Diego, CA). Nonesterified fatty acid concentration (NEFA) were analyzed using HR Series NEFA-HR(2) assay (Wako Life Sciences Inc., Mountain View, CA). Insulin and IGF-1 were analyzed using bovine insulin ELISA kit (ELBInsulin, Ray Biotech Inc., Norcross, GA). A VersaMax ELISA microplate reader with SoftMax PRO software (Molecular Devices LLC, Sunnyvale, CA) was used to conduct assays for haptoglobin, IgG, NEFA, insulin, and IGF-1.

\section{Statistical Analysis}

Milk, Milk Components, and Animal Variables. All statistical analyses were performed using $\mathrm{R}$ (version 3.3.2; R Core Team, 2016) according to the following model:

$$
Y_{i j k l}=\mu+T_{i}+P_{j}+(T \times P)_{i j}+C_{(i j) k}+e_{i j k l},
$$

where $Y_{i j k l}=$ dependent variable, $\mu=$ overall mean, $T_{i}$ $=$ fixed effect of treatment $(i=$ control or enzyme supplemented $), P_{j}=$ fixed effect of parity $(j=$ multiparous or primiparous), $(T \times P)_{i j}=$ fixed effect of interaction between treatment and parity, $C_{(i j) k}=$ random effect of cow $k$ nested within treatment and parity $(k=$ $1,2,3, \ldots, 20)$, and $e_{i j k l}=$ random error assumed to be independent and identically distributed from a normal distribution with a mean of 0 and variance of the error term $\sigma_{e}^{2}, \sigma^{2}\left[\sim N\left(0, \sigma_{e}^{2}\right)\right]$. All data were tested for normality using Shapiro-Wilk test and were normally distributed. Maximum likelihood was used to estimate parameters and standard errors. The compound symmetry covariance structure was used to adjust for all repeated measurements. Treatment differences were considered significant at $P<0.05$ and a tendency at $0.05<P<0.10$.

Blood Metabolites. All statistical analyses for blood metabolites was performed using $\mathrm{R}$ (version 3.3.2, $\mathrm{R}$ Core Team, 2016) according to the following model:

$$
\begin{gathered}
Y_{i j k l}=\mu+T_{i}+P_{j}+L_{k}+(T \times P)_{i j}+(T \times L)_{i k} \\
+(P \times L)_{j k}+C_{l}+e_{i j k l},
\end{gathered}
$$


where $Y_{i j k l}=$ dependent variable, $\mu=$ overall mean, $T_{i}$ $=$ fixed effect of treatment $(i=$ control or enzyme supplemented), $P_{j}=$ fixed effect of parity $(j=$ multiparous or primiparous), $L_{k}=$ fixed effect of lactation stage, $(T \times P)_{i j}=$ fixed effect of interaction between treatment and parity, $(T \times L)_{i k}=$ fixed effect of interaction between treatment and lactation stage, $(P \times L)$ $j_{k}=$ fixed effect of interaction between parity and lactation stage, $C_{l}=$ random effect of cow, and $e_{i j k l}=$ random error assumed to be independent and identically distributed from a normal distribution with a mean of 0 and variance of $\sigma^{2}\left[\sim N\left(0, \sigma_{e}^{2}\right)\right]$. The compound symmetry covariance structure was used to adjust for all repeated measurements.

Although the model initially carried all 2-way and 3 -way interactions of the fixed effects, only the interactions having considerable effects $(P<0.10)$ were included in the final model. The effects of $\beta$-mannanase on blood NEFA concentrations were analyzed with the model above excluding all the interactions. All response variables were log-transformed using the BoxCox power transformation method. Least squares means of those variables were transformed back to absolute values for presentation in tables. Multiple comparisons of the least squares means of factors having significant effects were carried out using the Tukey-Kramer adjustments test. The statistical analyses were carried out using the
"MASS," "lme4," "lmerTest," and "lsmeans" packages in R statistical software. Statistical differences were declared at $P<0.05$, and a tendency toward significance was considered at $0.05<P<0.10$.

\section{RESULTS AND DISCUSSION}

\section{Milk Yield and Production Parameters}

Milk yield and ECM did not differ between treatments (Table 2), which is in line with previous studies on fibrolytic exogenous enzymes, including endoglucanase and xylanase, in dairy cows (e.g., Arriola et al., 2011). As expected, multiparous cows had greater MY than primiparous cows $(P<0.001)$. To evaluate a possible response to the enzyme supplementation at different stages of lactation, a new categorical variable, period with 2 levels (early: experimental wk 1 to 10 and mid: experimental wk 11 to 24) was introduced into the statistical model. The effect of treatment on MY was significantly different between periods (treatment $\times$ period interaction; $P=0.011$ ). Multiparous cows in both groups produced more milk during early lactation than mid lactation, and enzyme supplementation did not influence MY.

In line with MY, DMI was greater for multiparous cows than primiparous cows $(31.6 \pm 0.40$ vs. $22.7 \pm$ $0.40 \mathrm{~kg} / \mathrm{d}$, respectively; $P<0.001)$. No effect of treat-

Table 2. Effect of dietary supplementation with $\beta$-mannanase ${ }^{1}$ on milk yield and composition, feed efficiency, BW and DIM of lactating dairy cows

\begin{tabular}{|c|c|c|c|c|c|c|c|c|c|}
\hline Item & \multicolumn{6}{|c|}{ Parity $^{2}$} & & & \\
\hline Milk yield (kg/d) & 47.6 & 47.2 & 2.78 & 35.2 & 34.9 & 2.34 & 41.5 & 41.1 & 3.38 \\
\hline $\operatorname{ECM}(\mathrm{kg} / \mathrm{d})$ & 45.4 & 44.9 & 2.53 & 34.1 & 33.6 & 1.49 & 39.8 & 39.2 & 3.01 \\
\hline $\mathrm{ECM} / \mathrm{DMI}$ & 1.45 & 1.53 & 0.08 & 1.42 & 1.49 & 0.09 & 1.49 & 1.45 & 0.06 \\
\hline $\mathrm{CP}$ intake $(\mathrm{kg} / \mathrm{d})$ & 5.92 & 6.03 & 0.39 & 4.25 & 4.36 & 0.25 & 5.09 & 5.2 & 0.45 \\
\hline BW (kg) & 747 & 720 & 32.2 & 642 & 615 & 38.8 & 699 & 663 & 22.0 \\
\hline Change in $\mathrm{BW}(\mathrm{kg} / \mathrm{d})$ & 0.33 & 0.38 & 0.34 & 0.35 & 0.4 & 0.23 & 0.34 & 0.39 & 0.21 \\
\hline \multicolumn{10}{|l|}{ Milk composition } \\
\hline Fat $(\%)$ & 3.72 & 3.77 & 0.21 & 3.87 & 3.92 & 0.19 & 3.8 & 3.85 & 0.14 \\
\hline Protein (\%) & 3.24 & 3.19 & 0.12 & 3.21 & 3.16 & 0.12 & 3.22 & 3.18 & 0.08 \\
\hline MUN (mg/dL) & 14.9 & 15.8 & 0.98 & 14 & 14.9 & 1.16 & 14.4 & 15.4 & 0.75 \\
\hline Fat $(\mathrm{kg} / \mathrm{d})$ & 1.77 & 1.77 & 0.12 & 1.36 & 1.35 & 0.06 & 1.57 & 1.56 & 0.12 \\
\hline Protein $(\mathrm{kg} / \mathrm{d})$ & 1.54 & 1.5 & 0.09 & 1.13 & 1.09 & 0.05 & 1.34 & 1.29 & 0.11 \\
\hline Lactose $(\mathrm{kg} / \mathrm{d})$ & 2.32 & 2.32 & 0.14 & 1.75 & 1.75 & 0.13 & 2.03 & 2.03 & 0.16 \\
\hline
\end{tabular}

${ }^{1}$ Control = no supplementation; Enzyme $=\beta$-mannanase supplementation $(0.1 \%$ of concentrate DM).

${ }^{2}$ Multiparous $=$ more than 1 lactation; Primiparous $=$ less than 1 lactation; Overall $=$ treatment groups without parity effect. 
ment was found to influence DMI $(P=0.57$ and $P=$ 0.79 , respectively). Across treatments, DMI increased in a diminishing return type curve until peak lactation, following the same increase and decrease pattern found in lactation curves reported in other studies (e.g., Kramer et al., 2009). Feed conversion efficiency was not affected by enzyme supplementation $(P=0.63)$ or by parity $(P=0.62)$. Feed efficiency was greater in early lactation than in mid lactation $(P<0.001)$. Body weight was influenced $(P<0.001)$ by parity. Multiparous cows were heavier $(P<0.001)$ than primiparous cows (Table 2). Average BW was higher in mid lactation than in early lactation $(P=0.03 ; 697$ vs. $661 \mathrm{~kg})$. No effects of $\beta$-mannanase supplementation were found on BW or BW change (Table 2).

\section{Milk Composition}

Supplementation of $\beta$-mannanase did not affect concentrations of milk components or yields of milk fat and protein (Table 2). Parity influenced milk fat, protein, and lactose yields. However, fat, protein, MUN, Ca, and P concentrations remained unaffected by parity. Previous experiments in lactating cows fed fibrolytic enzymes reported slight but statistically insignificant changes in milk fat (Romero et al., 2016) and milk protein percentage (Zheng et al., 2000). Sutton et al. (2003) reported increases in milk protein in cows supplemented with exogenous fibrolytic enzymes added to the concentrate portion of the diet; however, in most studies, no changes in milk fat and milk protein percentages were reported, in agreement with our results (Yang et al., 2000). Addition of $\beta$-mannanase numerically increased the concentrations of MUN $(P=$ $0.16 ; 15.4$ vs. $14.4 \mathrm{mg} / \mathrm{dL}$ ) and numerically decreased concentration of $\mathrm{P}$ in milk compared with the control group $(P=0.12,0.91$ vs. $0.96 \mathrm{~g} / \mathrm{L})$.
No treatment $\times$ parity interactions were detected for milk concentration parameters, feed efficiency, ECM, DMI, or BW, with the exception of lactose yield and lactose and SNF concentrations in milk. Although SNF concentrations were lower in the supplemented group during early lactation compared with mid lactation $(P$ $<0.001$; data not shown), SNF concentrations did not differ between treatments. Lactose concentrations, on the other hand, were significantly greater in the control group in early lactation compared with mid lactation $(P=0.003$; data not shown) but milk lactose concentrations did not differ between treatments. Lactose concentrations in the supplemented group remained unaffected across early- and mid-lactation periods.

\section{Effect of Enzyme on Immune and Metabolic Markers}

Concentrations of immune and metabolic markers are given in Table 3. Multiparous cows fed $\beta$-mannanase had significantly lower $(P=0.02)$ haptoglobin concentrations (0.50 vs. $0.42 \mathrm{mg} / \mathrm{mL}$ for control and enzymesupplemented cows, respectively). Haptoglobin has been identified as a major acute phase protein in ruminants that can be used to detect onset of systemic inflammation, including mastitis, endometritis, and pneumonia (Eckersall and Bell, 2010). Therefore, $\beta$-mannanase supplementation might exhibit an anti-inflammatory effect by decreasing acute phase responses.

Immunoglobulin $\mathrm{G}$ levels between the control and supplemented groups were not statistically different $(P$ $=0.30$ ), regardless of parity. Herr et al. (2011) highlighted a link between decreased IgG concentration and suppressed immune function in transition cows, which was not affected by parity. Tewoldebrhan et al. (2017) reported a significant reduction in SCC for cows supplemented with $\beta$-mannanase, but no difference was detected in this study. Although the SCC numbers of

Table 3. Effect of $\beta$-mannanase supplementation on concentrations of immune markers in cows fed diets with or without enzyme supplementation ${ }^{1}$

\begin{tabular}{|c|c|c|c|c|c|c|c|c|c|}
\hline \multirow{2}{*}{ Item } & \multicolumn{6}{|c|}{ Parity $^{2}$} & & & \\
\hline & \multicolumn{3}{|c|}{ Multiparous $(\mathrm{n}=10)$} & \multicolumn{3}{|c|}{ Primiparous $(\mathrm{n}=10)$} & \multicolumn{3}{|c|}{ Overall $(\mathrm{n}=20)$} \\
\hline Haptoglobin $(\mathrm{mg} / \mathrm{mL})$ & $0.50^{\mathrm{a}}$ & $0.42^{\mathrm{b}}$ & 0.04 & 0.48 & 0.49 & 0.04 & 0.49 & 0.46 & 0.04 \\
\hline $\operatorname{IgG}(\mathrm{g} / \mathrm{L})$ & 10.3 & 12.6 & 2.29 & 10.3 & 12.7 & 2.43 & 10.3 & 12.6 & 2.36 \\
\hline $\mathrm{SCC}\left(\times 10^{3} / \mathrm{mL}\right)$ & 41.6 & 18.7 & 18.9 & 27.9 & 29.6 & 18.4 & 33.9 & 23.4 & 18.6 \\
\hline Insulin $(\mu \mathrm{g} / \mathrm{mL})$ & 3.24 & 2.58 & 0.94 & 4.32 & 2.87 & 0.95 & 3.78 & 2.73 & 0.67 \\
\hline IGF-1 $(\mu \mathrm{g} / \mathrm{mL})$ & 0.147 & 0.103 & 0.10 & 0.156 & 0.146 & 0.10 & 0.151 & 0.124 & 0.07 \\
\hline
\end{tabular}

\footnotetext{
${ }^{\mathrm{a}, \mathrm{b}}$ Means within a row with different superscripts differ $(P<0.05)$.

${ }^{1}$ Control $=$ no supplementation; Enzyme $=\beta$-mannanase supplementation $(0.1 \%$ of concentrate DM $)$.

${ }^{2}$ Multiparous $=$ more than 1 lactation; Primiparous $=$ less than 1 lactation; Overall $=$ treatment groups without parity effect.
} 
enzyme-supplemented cows in the current trial were lower than those reported by Tewoldebrhan et al. (2017; 24,200 vs. 59,000 cells/mL, respectively), we did not see a significant difference, perhaps because the SCC of control cows in the current trial were already less than half of what was observed in the previous trial $(34,750$ vs. 72,000 cells $/ \mathrm{mL}$ ). Nyman et al. (2016) reported that SCC level of 74,000 cells/mL or above may indicate intramammary infections, which is over twice what was observed in this study on average.

Blood NEFA concentrations tended to be lower in the $\beta$-mannanase group than in controls, regardless of parity (Table $3 ; P=0.08$ ). Average NEFA concentrations in the first $10 \mathrm{wk}$ of the study were consistently lower in the enzyme group than in the control group during early lactation (data not shown). A trend toward lower NEFA concentrations in supplemented cows may indicate reduced lipid mobilization. Activation of the immune system has been found to consume a considerable amount of available energy and thereby worsen negative energy in the early stage of lactation. Kvidera et al. (2017) activated the immune system of lactating dairy cows using LPS, a PAMP, with and without a glucose infusion. They found lower NEFA concentrations in LPS-challenged cows with glucose supplementation than in those without it. Considering the improvements in haptoglobin and SCC responses, $\beta$-mannanase could lessen potential immune activation and thereby improve energy balance in lactating dairy cows.

We detected no significant differences in insulin concentrations between the control and enzyme treatment groups, regardless of parity (Table $3 ; P=0.14$ ). This may be due to the lack of metabolic challenge within both the control and enzyme treatment groups. Previous research testing the effects of insulin and NEFA concentrations suggested a negative correlation between the 2 biomarkers. For instance, Hayirli (2006) suggested that low insulin concentrations paired with low insulin sensitivity of tissues can create lipid mobilization, thus, increasing NEFA concentrations. Additionally, increased NEFA concentrations have been linked to reduced glucose-induced insulin responsiveness (Oikawa and Oetzel, 2006).

We investigated the effect of $\beta$-mannanase supplementation on reproductive parameters. There was no significant difference in days open (126 vs. $99.2 \mathrm{~d}$ for control and treatment cows, respectively; $P=0.196$ ); however, cows supplemented with $\beta$-mannanase tended to require fewer inseminations per successful conception than control cows (2.8 vs. 1.7 for control and treatment cows, respectively; $P=0.098$ ).

\section{CONCLUSIONS}

Addition of $\beta$-mannanase to the corn-silage fraction of a TMR during early and mid lactation did not affect milk yield or concentrations and yields of fat, protein, and Ca. Among the metabolic markers studied, haptoglobin levels tended to be lower in enzyme-supplemented cows regardless of parity, potentially indicating antiinflammatory effects of $\beta$-mannanase. The interactions between lactation stages and treatment, particularly in haptoglobin concentration, suggested a possible different response to enzyme supplementation at various lactation stages.

\section{ACKNOWLEDGMENTS}

This research was supported by CTC Bio Inc. (Seoul, South Korea). The authors also acknowledge the Sesnon Endowment Fund of University of California, Davis. The authors are grateful for assistance provided by Doug Gisi and Sharlie Folsom (University of CaliforniaDavis, Davis, CA).

\section{REFERENCES}

AOAC International. 2000. Official Methods of Analysis. 17th ed. AOAC International, Arlington, VA.

Arriola, K. G., S. C. Kim, C. R. Staples, and A. T. Adesogan. 2011. Effect of fibrolytic enzyme application to low- and high-concentrate diets on the performance of lactating dairy cattle. J. Dairy Sci. 94:832-841.

Ausubel, F. M. 2005. Are innate immune signaling pathways in plants and animals conserved? Nat. Immunol. 6:973-979.

Bradford, B. J., K. Yuan, J. K. Farney, L. K. Mamedova, and A. J. Carpenter. 2015. Invited review: Inflammation during the transition to lactation: New adventures with an old flame. J. Dairy Sci. 98:6631-6650.

Chauhan, P. S., N. Puri, P. Sharma, and N. Gupta. 2012. Mannanases: Microbial sources, production, properties and potential biotechnological applications. Appl. Microbiol. Biotechnol. 93:1817-1830.

Duncan, C. J. G., N. Pugh, D. S. Pasco, and S. A. Ross. 2002. Isolation of galactomannan that enhances macrophage activation from the edible fungus Morchella esculenta. J. Agric. Food Chem. 50:5683-5685.

Eckersall, P. D., and R. Bell. 2010. Acute phase proteins: Biomarkers of infection and inflammation in veterinary medicine. Vet. J. 185:23-27.

Fernando, S. C., H. T. Purvis 2nd, F. Z. Najar, L. O. Sukharnikov, C. R. Krehbiel, T. G. Nagaraja, B. A. Roe, and U. Desilva. 2010. Rumen microbial population dynamics during adaptation to a high grain diet. Appl. Environ. Microbiol. 76:7482-7490.

Forsberg, N. E., and Y. Wang. 2006. Nutrition and immunity in dairy cattle: Implications to hemorrhagic bowel syndrome. Proc. Prince Agri. Products Inc. Summit. Accessed Dec. 18, 2018. https://www .txanc.org/docs/Forsberg-manuscript-final.pdf.

Goering, H. K., and P. J. Van Soest. 1970. Forage fiber analyses. Agriculture Handbook. Agricultural Research Service, USDA, Washington, DC.

Hall, M. B. 2009. Determination of starch, including maltooligosaccharides, in animal feeds: Comparison of methods and a method recommended for AOAC collaborative study. J. AOAC Int. 92:42-49. 
Hayirli, A. 2006. The role of exogenous insulin in the complex of hepatic lipidosis and ketosis associated with insulin resistance phenomenon in postpartum dairy cattle. Vet. Res. Commun. 30:749-774.

Heinrichs, A. J., C. M. Jones, and B. S. Heinrichs. 2003. Effects of mannan oligosaccharide or antibiotics in neonatal diets on health and growth of dairy calves. J. Dairy Sci. 86:4064-4069.

Herr, M., H. Bostedt, and K. Failing. 2011. IgG and IgM levels in dairy cows during the periparturient period. Theriogenology 75:377-385.

Ikegami, S., F. Tsuchihashi, H. Harada, N. Tsuchihashi, E. Nishide, and S. Innami. 1990. Effect of viscous indigestible polysaccharides on pancreatic-biliary secretion and digestive organs in rats. J. Nutr. 120:353-360.

Jackson, M. E., D. M. Anderson, H. Y. Hsiao, G. F. Mathis, and D. W. Fodge. 2003. Beneficial effect of beta-mannanase feed enzyme on performance of chicks challenged with Eimeria sp. and Clostridium perfringens. Avian Dis. 47:759-763.

Kramer, E., E. Stamer, J. Spilke, G. Thaller, and J. Krieter. 2009 Analysis of water intake and dry matter intake using different lactation curve models. J. Dairy Sci. 92:4072-4081.

Kvidera, S. K., E. A. Horst, M. Abuajamieh, E. J. Mayorga, M. V. Sanz Fernandez, and L. H. Baumgard. 2017. Glucose requirements of an activated immune system in lactating Holstein cows. J. Dairy Sci. 100:2360-2374.

Li, Y. H., X. A. Chen, Y. Q. Chen, Z. M. Li, and Y. H. Cao. 2010. Effects of beta-mannanase expressed by Pichia pastoris in cornsoybean meal diets on broiler performance, nutrient digestibility, energy utilization and immunoglobulin levels. Anim. Feed Sci. Technol. 159:59-67.

Nakai, Y., M. Nakatani, T. Ando, T. Inamoto, and K. Ogimoto. 1994. Degradation of $\beta$-mannan by rumen bacteria. Nihon Chikusan Gakkaiho 65:443-446.

NRC. 2001. Nutrient Requirements of Dairy Cattle. 7th rev. ed. Natl. Acad. Press, Washington, DC.

Nyman, A. K., U. Emanuelson, and K. P. Waller. 2016. Diagnostic test performance of somatic cell count, lactate dehydrogenase, and $\mathrm{N}$-acetyl-beta-D-glucosaminidase for detecting dairy cows with intramammary infection. J. Dairy Sci. 99:1440-1448.

Oikawa, S., and G. R. Oetzel. 2006. Decreased insulin response in dairy cows following a four-day fast to induce hepatic lipidosis. J. Dairy Sci. 89:2999-3005.

R Core Team. 2016. R: A language and environment for statistical computing. R Foundation for Statistical Computing, Vienna, Austria. http://www.R-project.org/.
Romero, J. J., E. G. Macias, Z. X. Ma, R. M. Martins, C. R. Staples, K. A. Beauchemin, and A. T. Adesogan. 2016. Improving the performance of dairy cattle with a xylanase-rich exogenous enzyme preparation. J. Dairy Sci. 99:3486-3496.

Sordillo, L. M., and S. L. Aitken. 2009. Impact of oxidative stress on the health and immune function of dairy cattle. Vet. Immunol. Immunopathol. 128:104-109.

Sutton, J. D., R. H. Phipps, D. E. Beever, D. J. Humphries, G. F. Hartnell, J. L. Vicini, and D. L. Hard. 2003. Effect of method of application of a fibrolytic enzyme product on digestive processes and milk production in Holstein-Friesian cows. J. Dairy Sci 86:546-556.

Swanson, K. S., C. M. Grieshop, E. A. Flickinger, L. L. Bauer, H. P. Healy, K. A. Dawson, N. R. Merchen, and G. C. Fahey Jr.. 2002. Supplemental fructooligosaccharides and mannanoligosaccharides influence immune function, ileal and total tract nutrient digestibilities, microbial populations and concentrations of protein catabolites in the large bowel of dogs. J. Nutr. 132:980-989.

Tewoldebrhan, T. A., J. A. D. R. N. Appuhamy, J. J. Lee, M. Niu, S. Seo, S. Jeong, and E. Kebreab. 2017. Exogenous $\beta$-mannanase improves feed conversion efficiency and reduces somatic cell count in dairy cattle. J. Dairy Sci. 100:244-252.

US EPA (Environmental Protection Agency). 1994. Method 200.7, Revision 4.4: Determination of metals and trace elements in water and wastes by inductively coupled plasma-atomic emission spectrometry. Accessed Nov. 4, 2018. https://www.epa.gov/sites/ production/files/2015-08/documents/method_200-7_rev_4-4 -1994.pdf.

Van Soest, P. J., J. B. Robertson, and B. A. Lewis. 1991. Methods for dietary fiber, neutral detergent fiber, and nonstarch polysaccharides in relation to animal nutrition. J. Dairy Sci. 74:3583-3597.

Yang, H., P. Shi, H. Lu, H. Wang, H. Luo, H. Huang, P. Yang, and B. Yao. 2015. A thermophilic beta-mannanase from Neosartorya fischeri $\mathrm{P} 1$ with broad $\mathrm{pH}$ stability and significant hydrolysis ability of various mannan polymers. Food Chem. 173:283-289.

Yang, W. Z., K. A. Beauchemin, and L. M. Rode. 2000. A comparison of methods of adding fibrolytic enzymes to lactating cow diets. J. Dairy Sci. 83:2512-2520.

Zheng, W., D. J. Schingoethe, G. A. Stegeman, A. R. Hippen, and R. J. Treacher. 2000. Determination of when during the lactation cycle to start feeding a cellulase and xylanase enzyme mixture to dairy cows. J. Dairy Sci. 83:2319-2325. 